\title{
Histopathologic Examination of The Effects of Cyclosporin A Alone And The Combined Therapy with Prednisolone on Lung: An Experimental Study
}

\author{
Aktas $\mathrm{RG}^{*}$, Altaner $\mathrm{S}^{* *}$, Guven $\mathrm{A}^{* * *}$, Coskun $\mathrm{O}^{*}$, Barut $\mathrm{C}^{*}$, Ozen OA* \\ *Zonguldak Karaelmas University, Faculty of Medicine, Zonguldak, TURKEY \\ **Trakya University, Faculty of Medicine, Edirne, TURKEY \\ *** Abant Izzet Baysal University, Duzce Medical Faculty, Duzce, Bolu, TURKEY \\ Cyclosporin-A(CsA) is a very potent immunosuppressive agent which is widely used in \\ transplantations and autoimmune diseases. Recent studies suggest an encouraging clinical effect \\ for low-dose, long-term cyclosporin A treatment in different lung diseases[1,2,3,4,5]. Whether \\ administration of CsA might be useful for lowering the dosage of steroids during the treatment of \\ interstitial pneumonia, asthma and lung injuries[6,7,8] is presently a matter of controversy. \\ Several clinical studies reported that CsA might cause pulmonary complications in transplant \\ recipients $[9,10]$.
}

The aims of this experimental study were: (i) to examine the effects of CsA on lung at morphologic level and to verify the tolerability of long-term, low-dose treatment with this drug; (ii) to analyze if Cremophor-EL(the vehicle in the intravenous form of CyA) is responsible from the changes; (iii) to investigate if combined therapy with Prednisolone has better morphologic results on lung tissue.

Forty-eight female Sprague-Dawley rats were divided into four groups: Group I was control. The other three group had daily intraperitoneal injection of $4 \mathrm{mg} / \mathrm{kg} / \mathrm{day}$ CyA for 2,5 months. Group II had oral, Group III had intravenous form of this drug while Group IV had intravenous form of CsA with $1 \mathrm{mg} / \mathrm{kg} /$ day prednisolone. Biopsy specimens from lung were embedded in paraffin and the sections were stained with Hematoxylene \& Eosin for microscopic examination.

The results of the experiment were summarized in Table 1. Amphysema, pneumonia and acute pulmonary oedema were the most common complications. Histopathologic findings were common in Group II. The incidences of some findings were decreased in Group III at some degree. Group IV had the least pathological findings.

We conclude that either oral or intravenous form of CsA might cause pulmonary complications. There was no significant difference between the results of Group II and Group III. This suggests that the vehicle, Cremophore-EL, is not responsible for these morphological changes. There are several retrospective clinical studies showing 8-16\% incidence of pneumonia and $18-37 \%$ incidence of other pulmonary complications after renal transplantation[ 9,10$]$. We observed higher incidence of the complications in our experimental study. We hypothesize that CsA might be added to the steroid therapy if it is needed, since the incidences of histopathologic findings decreased after administration of Prednisolone with CsA . 


\section{References}

[1] Dzik JM et al. Acta Biochim Pol 49(2002)233.

[2] Miyake S et al. Sarcoidosis Vasc Diffuse Lung Dis 19(2002)128.

[3] Underwood SL et al. Eur J Pharmacol 420(2001)165.

[4] Matthew E et al. Am J Physiol 276(1999)L786.

[5] Losa Garcia JE et al. Respir Med 92(1998)722.

[6] Evans DJ et al. Cochrane Database Syst Rev 2(2001)CD002993.

[7] Lock SH et al. Am J Respir Crit Care Med 153(1996)509.

[8] Zappasodi P et al. Ann Hematol 81(2002)347.

[9] Edelstein CL et al. S Afr Med J 85 (1995) 160.

[10]Ettinger NA and Trulock EP. Am Rev Respir Dis 143(1991)1386.

[11] This study was supported by Sandoz Ltd.

TABLE 1. Comparison of pulmonary histopathologic findings after the administration of oral form of CsA(Group II), intravenous form of CsA(GroupIII), and the combined therapy of intravenous form CsA with Prednisolone ( Group IV). Group I was control. No: Number of specimens showing the histopathologic finding.

\begin{tabular}{|l|l|l|l|l|l|l|l|l|}
\hline $\begin{array}{l}\text { Histopathologic } \\
\text { Findings* }\end{array}$ & $\begin{array}{l}\text { Group } \\
\text { I }\end{array}$ & \multicolumn{2}{l}{$\begin{array}{l}\text { Group } \\
\text { II }\end{array}$} & $\begin{array}{l}\text { Group } \\
\text { III }\end{array}$ & \multicolumn{2}{l|}{$\begin{array}{l}\text { Group } \\
\text { IV }\end{array}$} \\
\cline { 2 - 10 } & No & \% & No & \% & No & \% & No & $\%$ \\
\hline Amphysema & 0 & 0 & 5 & 41,6 & 2 & 16,6 & 4 & 33,3 \\
\hline Bronchopneumonia & 0 & 0 & 2 & 16,6 & 0 & 0 & 0 & 0 \\
\hline Pneumonia & 0 & 0 & 6 & 50 & 6 & 50 & 6 & 50 \\
\hline Bronchitis & 0 & 0 & 2 & 16,6 & 2 & 16,6 & 0 & 0 \\
\hline Acute lung oedema & 0 & 0 & 4 & 33,3 & 4 & 33,3 & 4 & 33,3 \\
\hline Atelectesia & 0 & 0 & 4 & 33,3 & 2 & 16,6 & 0 & 0 \\
\hline Congetion & 0 & 0 & 2 & 16,6 & 2 & 16,6 & 2 & 16,6 \\
\hline No complication & 12 & 100 & 1 & 8,3 & 2 & 16,6 & 6 & 50 \\
\hline
\end{tabular}

*Some specimens showed more than one complication. 